\title{
Facing the future together: French and English in contrast
}

\author{
Raf Salkie \\ University of Brighton \\ r.m.salkie@bton.ac.uk
}

\section{Introduction}

It is often assumed that languages conceive of the future very differently from the past. The classic statement of this position is by John Lyons:

\begin{abstract}
... the future is not like the past from the point of view of our experience and conceptualization of time. Futurity is never a purely temporal concept; it necessarily includes an element of prediction or some related modal notion. (1977: 677)
\end{abstract}

This assumption has led many linguists to reject an analysis of the French future inflection (henceforth FFI) and English will as "purely temporal". For French we can cite Paul Larreya, who writes:

Le sémantisme fondamental de la forme en -RAI n'est pas, en fait, l'expression du futur. Ce sémantisme est de nature modale, et non temporelle. (1996: 146).

Similar views were put forward by Fuchs \& Léonard (1979) and de Vogüé (1993), for whom "le futur ne renvoie pas en soi aux temps futurs: il n'y renvoie que parce qu'il construit" (1993: 84). Handbooks of French grammar which reject an underlying temporal analysis of FFI include Riegel et al. (1994) and Levy (2000). For English, an analysis of will as fundamentally modal in its semantics was defended by Huddleston (1995), and has been adopted by most handbooks - from Jespersen (1933) to Biber et al. (1999).

Some grammarians have criticised these positions: Vetters (1996) for French and English, Vet (2003) for French, and Kissine (2008) for English are notable examples. This paper aims to demonstrate that a contrastive perspective supports these critical voices. We maintain that both FFI and will are basically markers of future tense, and that the only semantic difference between them is is that will also retains a volitional element of meaning from its historical evolution.

The most important contrastive studies of future time reference in French and English are by Agnès Celle, notably Celle (1994, 1997, 2005, 2006). She claims that FFI and will differ fundamentally in their semantics, and that the differences in their use can be explained by these semantic differences. In her view, "le futur [français] est ... fondamentalement un marqueur de rupture par rapport à la situation d'énonciation" (2006: 113), while will expresses "adequate assurance" in which "the parameter that prevails is modal" $(2005: 184 ; 186)$. We argue here that the semantic difference between FFI and will is in fact minimal, and that the contrasts analysed by Celle can be explained in other ways: partly on pragmatic grounds, and partly on the basis of different textual strategies in the two languages. The analysis is supported by data from a parallel corpus of French and English, the INTERSECT corpus (Salkie 2008).

\section{Future time reference in French}

The null hypothesis for French, which I shall assume here, is that FFI simply means "speech time precedes event time". In examples like (1-6), this seems to be the sense expressed:

(1) Il s'agit d'une question supplémentaire, néanmoins le ministre peut y répondre brièvement, après quoi, je donnerai la parole au député de Champlain. [Canhans] 
(2) The question is not quite supplementary but the minister may reply briefly after which $\underline{I}$ will recognize the hon. member for Champlain.

(3) Puis, voyant sa tristesse, j'ajoutai moins brutalement: 'Tu m'aideras.' [Gide]

(4) Then, seeing how unhappy she looked, I added less roughly: 'You will help me'.

(5) La France et l'Allemagne, dans les prochains mois, seront confrontées au même défi : redéfinir une action extérieure tenant compte des bouleversements de l'après-guerre froide. [News]

(6) In the coming months, France and Germany will also be confronted by the same challenge of redefining foreign action in the context of the upheavals following the end of the Cold War.

(See the appendix for information about the corpus texts. Normally the original language version is given first). For our purposes, we need to recognise that the picture is more complicated in several ways. Firstly, the FFI morpheme can combine with other tense morphemes, notably to form the Future in the Past:

(7) Ces chiffres ne tiennent pas compte des 12 pour cent de répondants qui ne paieraient pas par mensualités. [Misc]

(8) These averages do not include responses from the 12 per cent who said they would not make monthly payments on a vehicle.

The verb paieraient contains a past tense morpheme along with the FFI morpheme, and the two morphemes combine to yield the sense "there is a reference time in the past, and event time is future in relation to that reference time": the reference time in (7) is the time in the superordinate clause when the responses were uttered. ${ }^{2}$ The notion of reference time is taken from Reichenbach (1947) and Comrie (1985), and simply means "another time in the context". It is trivial to define FFI and the past tense morpheme so that they do not always involve speech time and event time, but more generally a known time and a time which is located in relation to that unknown time:

FFI: known time precedes time to be located.

Past: time to be located precedes known time.

In the default case, the known time will be speech time and the time which is located in relation to it will be event time; but both times can alternatively be a reference time. The details do not need to concern us here, since - as the English version in (8) shows - the same phenomenon is found in English (assuming that would can similarly be analysed as will + past, as Huddleston (1995) argues extensively).

Secondly, French has other ways of referring to future time, such as the present tense in (9), aller + infinitive in (11), and devoir in (13):

(9) Demain je pars pour Budapest; dans six jours je dois être à Rome. [Gide]

(10) Tomorrow I leave for Budapest; in six days' time I must be in Rome

(11) La vieille mère Henrouille, tiens en voilà une qui va attraper une sacrée grippe. [Céline]

(12) "Old Mother H. is the one who's going to catch her death of cold!"

(13)... étant donné qu'une conférence mondiale sur l'alimentation doit se tenir à Rome en novembre, le ministre pourrait-il voir s'il est possible que les organisateurs en avancent la date ... [Canhans]

(14) ... in view of the fact there is a world conference on food scheduled in Rome in November, will the minister see if it is possible to get those responsible to advance the date ...

It is not unusual for a language to have more than one way of referring to the future (or, for that matter, the past). These other constructions are restricted in various ways, which we need not pursue here (cf. Vet 1993), whereas FFI is not restricted. We learn nothing about the semantics of FFI from the existence of these constructions. 
Thirdly, FFI can be used to express other things than simple future time. Some of the most important are illustrated here: characteristic properties in the present (15), willingness (17), and strong belief about a present situation (19) or a past situation (22):

(15) L'effet des tremblements de terre sur les structures élevées varieront [sic] d'un immeuble à l'autre et d'un étage à l'autre, mais on peut généralement s'attendre à ce qui suit : aux étages inférieurs, le tremblement sera plus rapide ... [Misc]

(16) The effect of an earthquake on a high-rise structure will vary from building to building and from floor to floor, but generally the following can be expected to happen: Lower floors will shake rapidly ...

(17)Le Canada acceptera-t-il l'invitation du maire et du Conseil de se faire représenter à SaintGeorges-des-Groseillers (France), lors des cérémonies de commémoration de la tragédie qu'ont vécue à cet endroit les troupes canadiennes, le 11 juin 1944 ... [Canhans]

(18)Will Canada accept an invitation extended by the Mayor and Council and be represented at Saint-Georges-des-Groseillers, France for the recognition of the wartime tragedy that was suffered by Canadian troops there on June 11, $1944 \ldots$

(19) Quant à la seconde partie, le député se rappellera sans aucun doute qu'au cours de la dernière législature certaines directives ont été présentées, que nous croyions utiles, dans le but d'allier le droit du Parlement et du peuple à connaître ... [Canhans]

(20) ... the honourable member will no doubt recall that in the last parliament we tabled guidelines, which we thought were useful ones, which tried to combine the right of parliament and people to know ...

(21) If, then, our diagram be assumed to represent a considerable amount of modification, species (A) and all the earlier varieties will have become extinct, being replaced by eight new species ... [Scitec]

(22) Si donc on suppose que notre diagramme représente une somme considérable de modifications, l'espèce A et toutes les premières variétés qu'elle a produites, auront été éliminées et remplacées par huit nouvelles espèces...

These ways of using a future tense are found in other languages, such as Italian (Rocci 2000) and German (Welke 2005), along with English, as examples (16), (18), (20) \& (21) indicate. We do not need to modify the claim that FFI basically has a temporal semantics.

\section{Contrasts between FFI and English will}

So far every French example except (13) has had a parallel English example with will, and this supports the null hypothesis for English that will is also a marker of future tense. The global figures from the corpus also provide some support for the hypothesis. Using a 300,000 word subcorpus from INTERSECT, balanced equally for fiction and non-fiction texts, we found 1192 instances of FFI, of which $1000(83.9 \%)$ had as their translation equivalent either will or shall or 'll. In the other direction, there were 651 instances of will, 480 of them (67.6\%) corresponding to FFI. The lower percentage for English to French correspondences is not surprising: as we shall see directly, will has uses which FFI lacks. Let us examine if the non-correspondences can be accounted for while still maintaining the null hypothesis that both FFI and will are markers of future tense.

\subsection{English to French}

Of the 171 instances where will did not correspond to FFI, the largest single group (61 instances) used the present tense in French. We can distinguish 22 examples where will expresses a characteristic property (cf. (16) above) but the French version does not use FFI, illustrated in (23-6): 
(23) It seems that there is also a definite quantum of parasites the presence of which in the blood will cause febrile symptoms [Whomal]

(24) Il semble aussi qu'il existe, en ce qui concerne le nombre de parasites, un seuil précis au-delà duquel leur présence dans le sang cause des symptômes fébriles.

(25) Depending on which version you have, your Multipractic will come with one or two slicing discs (top picture) for fine or coarse slicing, or with an adjustable slicing systems (bottom picture). [Instrs]

(26) Suivant l'équipement de votre appareil, vous avez un ou deux disques éminceurs (photo du haut) pour râper finement ou grossièrement ou bien un éminceur adaptable (photo du bas).

Although French can use FFI in some instances of this kind, as we saw in (15) above, it is less common than will: cf. Celle (1994: 131-7) for discussion.

In the remaining 39 instances where French used the present tense, it is difficult to discern any recurrent patterns:

(27) In these conditions the identity of Europe and eventually its political independence will be seriously at stake. [Intorgs]

(28) Dans ces conditions, l'identité de l'Europe et finalement son indépendance politique sont en jeu.

(29)Ils n'ont pas davantage été capables de réduire la progression des dépenses de retraite qui pèsent sur les générations montantes, ni de créer les conditions d'une croissance plus riche en emplois ou de limiter les inégalités. [News]

(30) They have not been able to hold down the increasing cost of pensions which will be a burden on coming generations, nor create the conditions for a growth generating more jobs or reduce inequalities.

(31) Il a décidé de remplacer ce camion le plus tôt possible, et c'est bien la dernière fois - dit-il qu'il achète du vieux matériel militaire. [Robbeg]

(32) He has decided to replace the truck as soon as possible, and it's the last time - he says - that he will buy old military materiel.

(33) Le secrétaire général doit prendre des mesures pour vaincre une paralysie d'autant plus regrettable que des programmes de l'ONU du rapatriement des réfugiés en passant par un début de déminage ou de premiers efforts de réhabilitation d'une infrastructure en ruine ont été entrepris avec succès. [News]

(34) The secretary-general will have to take steps to overcome a paralysis which is all the more regrettable as UN programmes like refugee repatriation, mine clearance, and infrastructure rehabilitation have been successfully initiated.

Examples (31-2) are a familiar type of contrast to anyone who knows the two languages, though this was the only example of its kind in the subcorpus; and there were two other instances similar to (33-4) where French doit corresponds to will have to.

Another frequent equivalent was aller + infinitive (31 instances):

(35) Can the minister tell the House if this trend toward a lower gross national product will continue in 1974 ? [Canhans]

(36) Le ministre peut-il dire à la Chambre si cette tendance à la baisse du produit national brut va se poursuivre en 1974 ?

The difference between FFI and aller + infinitive is less clear-cut than the difference between will and be going to in English. Whereas be going to requires a definite connection with the present moment, aller + infinitive tends to be used instead of FFI in case there is no sharp break between the present situation and 
the future situation (cf. Celle (1997: 26) - as Celle notes, in her data aller + infinitive usually corresponds to will in English, rather than to be going to).

Three other types of equivalent of will were 13 instances of the future in the past (e.g. 37-8), 13 of the subjunctive (39-40), and 11 of devoir (41-2):

(37) Ils n'ont pas précisé s'ils prendraient ceux-ci chacun de son côté, ou s'ils se retrouveraient pour les prendre ensemble. [Robbeg]

(38) They have not specified whether they will take their meals separately or if they will meet to have them together

(39)ISO and CEN (European Committee for Standardization), for example, have defined procedures for the development of standards that will be acceptable both as European Standards and as International Standards. [Scitec]

(40) L'ISO et le CEN (Comité européen de normalisation), par exemple, ont défini des procédures pour l'élaboration de normes qui soient acceptables à la fois comme Normes européennes et comme Normes internationales.

(41)In view of the fact that we were given a mandate which in the normal course of events will last some four years more or less, we have to assume that the people of Canada do want this government to tackle tasks which are of longer duration than perhaps one or two sessions. [Canhans]

(42) Comme notre mandat doit normalement durer environ quatre ans ou moins, nous devons supposer que les Canadiens tiennent à ce que le gouvernement actuel s'attèle à des tâches d'une plus longue durée peut-être que celle d'une ou de deux sessions.

Space prohibits closer analysis of these interesting examples, but they do not appear to threaten the null hypothesis. Nor do the cluster of 24 equivalents which avoid using a tense altogether, or use a very different construction, for example:

(43) The Options category indicates the interactive tools that you will be using to assist ScanWorX. [Instrs]

(44) La catégorie Options indique les outils interactifs à votre disposition pour aider ScanWorX.

(45) The objective: to provide European IT Industry with the technology base it will need to become and stay competitive world-wide within the next ten years. [Intorgs]

(46) Le programme a pour objectif de fournir à l'industrie européenne de la technologie de l'information la base technologique nécessaire pour lui permettre de devenir et de rester compétitive au niveau mondial au cours des dix prochaines années.

(47) He will no doubt recall that when we did mention it in the first Speech from the Throne in the last parliament ... [Canhans]

(48) Je lui rappelle que nous en avons parlé dans le discours du trône de la dernière législature ...

We would expect to find some "noise" of this kind among equivalents of will.

We saw that 171 instances of will did not correspond to FFI $-32.4 \%$ of the total. Of these 171 , we have examined 61 that used the present tense, 31 with aller + infinitive, 13 which had the future in the past, 13 with the subjunctive, 11 that used devoir, and 24 "noisy" equivalents, a total of 153 . That leaves only 18 ( $2.8 \%$ of the total) to be accounted for, and we might reasonably expect that such a small proportion would not threaten the null hypothesis - except for a group of 5 examples where the French uses vouloir, including: 
(49) "But how," said I, "can it have remained so long undiscovered, when there is a sure index to it if men will but take the trouble to look?" [Efict]

(50) - Mais comment ces trésors peuvent-ils être restés enterrés si longtemps, alors que tout homme qui veut se donner un peu de mal pourrait les découvrir, grâce aux flammes bleues?

(51) He answered, "Yes, certainly," and added: "You may go anywhere you wish in the castle, except where the doors are locked, where of course you will not wish to go." [Efict]

(52) - Mais bien entendu ! Vous pouvez aller où vous le désirez, dans ce château, sauf dans les chambres fermées à clé et où, bien entendu, vous ne voudriez pas pénétrer.

(53) "Will you get me some matches?" said the visitor, quite abruptly. [Efict]

(54) - Voulez-vous me donner des allumettes? fit brusquement l'étranger.

Here we have to accept that there is a significant difference between FFI and will, because FFI is not normally used to express volition. We therefore modify our analysis of will and accept that this word has retained volition as part of its meaning over the centuries during which it evolved from Old English willan "to want". Although the 5 corpus examples are a very small number, they all occur in fictional dialogue, suggesting that this use of will is more common in spoken English. Haegeman (1983) argues that this element of meaning is only triggered in certain specific contexts and thus has a pragmatic basis: the proposition must be "compatible with the imperative mood, persuasive constructions and with volitional adverbials as intentionally" (1983: 86). She does not, however, contrast will with other languages where this does not happen: once we do this, it is clear that FFI does not express volition and is just a future tense marker, whereas will is different. Volition is sometimes called a "modal" use of will (for example, Huddleston 1995: 424), but that label is misleading: none of the core modals of English (may, must, can, should) expresses volition. It is more accurate to regard this use of will as a relic of the history of this lexical item rather than indicating any semantic property shared with other modals.

\subsection{French to English}

In this direction the absolute number of examples that did not use the future tense marker in the other language was larger (192) than for English to French, but the percentage was smaller (16.1\%) because of the far higher total number of instances (1192). The largest group among the 192 used the present tense (67 instances), including:

(55)Que celui qui en souffre l'accepte ou lutte contre elle, elle sera toujours passive.[Malmau]

(56) Whether he who suffers from it accepts or struggles against such a passion, it is always passive.

(57) The existing antimalarial drugs are described below in the following groups, in relation to their chemical structure and their biological activity. [Whomal]

(58) Les antipaludiques existants, dont on trouvera plus loin la description, sont classés comme suit en fonction de leur structure chimique et de leur activité biologique:

Examples like these show no recurrent patterns, as we found with (27-34) where English used will and French had the present tense. Example (59), however, illustrates a well-known difference between French and English: in subordinate clauses introduced by lorsquelquand, FFI is used, while English when-clauses typically use the present tense for future time reference.

(59) We intend to be a constructive opposition, but a vigorous one, especially when the rights and paramount obligations of parliament are involved. [Canhans]

(60) Nous entendons faire une opposition constructive, mais énergique, surtout lorsque seront en jeu les droits et les attributions du Parlement. 
Examples (61-4) show that the same contrast is found is some types of relative clause - cf. Celle (1997: 47-8), who treats this as "une contrainte dans la traduction du futur [français]" which has to be noted but which does not in itself suggest semantic differences between FFI and will.

(61) Nous nous proposons, en les publiant, de préciser les mouvements de deux sensibilités, et de suggérer à ceux qui les liront des réflexions particulières sur la vie de leurs sens et de leur esprit, qui peut sembler singulière. [Malmau]

(62) By publishing them, we propose to delineate the developments of two sensibilities, and to suggest to those who read them some arresting thoughts on the seemingly unusual sensuous and spiritual lives of these two men.

(63) Save Template: Saves the current template in a template file of the name you assign. [Instrs]

(64) Sauvegarder gabarit : Sauvegarde le gabarit en cours dans un fichier de gabarit sous le nom que vous lui aurez attribué.

In (65-74), a modal expression using FFI corresponds to a simple modal expression in English: the examples show that this occurs with may (65), must (67), need (69), can (71) and be (un)likely (73). Examples (67-8) and (69-70) are similar to (61-2) in that FFI and its English equivalent occur in a relative clause.

(65) Also, recognition of documents with a lot of background noise, or with colored backgrounds, may improve considerably by using a lighter setting. [Instrs]

(66) En outre, la reconnaissance de documents présentant beaucoup de parasites, ou sur des fonds colorés, pourra être nettement améliorée par la sélection d'une instruction plus claire

(67) These are some of the things we must fight for, in the interests of a free society, during the life of this parliament. [Canhans]

(68) Voilà quelques-uns des points sur lesquels nous devrons lutter dans l'intérêt d'une société libre au cours de la présente législature

(69)This manual should provide all the information you need to operate ScanWorX. [Instrs]

(70) Ce manuel doit vous fournir toutes les informations dont vous aurez besoin pour exploiter ScanWorX.

(71) You can always try to back-track when the lost words pop back into your memory; but if they do not, all is not lost. [Misc]

(72) Si la mémoire vous revient, vous pourrez toujours rattraper votre bévue; sinon, vous n'aurez pas tout perdu.

(73) The situation has, however, reached such a state that even programmes on the scale of those now being considered in some of the larger Member States are unlikely in themselves to solve unaided the problem in Europe. [Intorgs]

(74)Cependant, la situation a atteint un stade où même des programmes de l'ampleur envisagée par certains grands états membres ne permettront pas à eux seuls de résoudre les problèmes auxquels l'Europe se trouve confrontée.

The general explanation for all these cases is that English modal verbs cannot appear in the complement of will because they do not have non-finite forms: they are often able to express futurity without the help of will (cf. Huddleston \& Pullum 2002: 160-2). This explanation does not account for (73-4), where will be unlikely is grammatically possible: however, be (un)likely with a dynamic verb like solve tends to convey that the event is (un)likely to take place in the future, so using will is not usually necessary. 
This type of translation is to be distinguished from the next type, where English uses a modal verb but French does not have a modal expression (53 examples):

(75) I have to be away till the afternoon. [Efict]

(76) Je serai absent jusque dans l'après-midi

(77) Toute chose à laquelle nous nous attachons, action ou pensée, nous voulons, selon les insinuations de notre sensibilité et de l'heure, pouvoir choisir entre les aspects successifs que lui donnera le temps. [Malmau]

(78) Depending upon the insinuations of our sensibility and of the moment, we want to be able to choose between the successive aspects time may give any object we are currently preoccupied with, be it action or thought.

(79) This latter objective can only be achieved through major advances in hardware (components) and software technology and systems architecture. [Intorgs]

(80) On n'atteindra ce dernier objectif qu'en accomplissant des progrès substantiels dans le domaine du matériel (composants), de la technologie du logiciel et de l'architecture des systèmes.

(81) For example, you might want to recognize the text of a document and process it to, say, Interleaf for desktop publishing purposes. [Instrs]

(82) Vous voudrez par exemple reconnaître le texte d'un document et le traiter en format Interleaf pour publication assistée par ordinateur

(83) - Et vous, Ferdinand, vous pensez aussi qu'ils la guériront n'est-ce pas ma mère? [Céline]

(84) "What d' you think, Ferdinand; don't you think they can cure her?"

(85) The modem needs only be tested at the maximum modulation rate of the equipment into which it is to be incorporated. [Scitec]

(86)Le fonctionnement sera normalement étudié par un essai donnant la marge de distorsion avant que les erreurs ne sortent de l'équipement.

Although these examples would repay careful analysis in a cross-linguistic study of modality, all we need to say here is that English has a tendency to use modal verbs, particularly can and may/might, in contexts where French does not use a modal expression. Example (85-6) is similar to the next type, where French uses FFI in instructions and English mostly uses an imperative (9 instances):

(87) If there's damage done, put it down in the bill. [Efict]

(88) S'il y a quelque dégât, vous l'ajouterez sur la note

(89) When chopping herbs such as parsley for garnishing, make sure both the herbs and working bowl are clean and dry before processing. [Instrs]

(90) Les ingrédients tels que le persil ou d'autres fines herbes seront traités de préférence â l'état sec dans un bol sec.

(91) The different numbering of this structure should be noted. [Whomal]

(92) On notera le numérotage différent de cette structure.

Celle discusses some similar examples (1997: 88-91), and once again these cases do not appear to jeopardise the null hypothesis for either language. 
A final distinct type is the group of 9 examples in which French uses FFI in narrative to look forward from a point in the past: English typically uses the simple past (94 \& 96), though translations which capture the notion of looking forward are also found, such as was to in (98) and afterwards in (100):

(93) De Gaulle organise à Paris la rencontre entre Khrouchtchev et les alliés occidentaux en mai 1960 (l'affaire de l'avion U2 la fera échouer. [Misc]

(94) De Gaulle organized a meeting in Paris between Khrushchev and the Western allies in May 1960 (it failed in the wake of the U2 affair).

(95) Deux semaines plus tard, Luis vient chez moi : « Serge, ce garçon est très intelligent, mais je ne peux pas continuer à travailler avec lui ; il est d'accord avec tout ce que je dis. » Manifestement, Jean-Claude Carrière apprendra vite à contredire Don Luis, juste ce qu'il faudra. Leur collaboration ne cessera plus. [News]

(96) Two weeks later, Luis said to me: "Serge, this fellow is very intelligent, but I can't go on working with him: he agrees with everything I say". Clearly Carriere soon learned to contradict Don Luis - to just the right degree. He worked on the screenplays of all Buñuel's French films after that.

(97) Mais l'armée, avec les jeunes appelés du contingent, intervient alors en Algérie dans un conflit qui, déclenché dès 1954, durera jusqu'en 1962. [Misc]

(98) But the French army, using young conscripts, became involved in Algeria in a conflict which broke out in 1954 and was to last until 1962.

(99) Un dîner presque tout frugal était prêt dans un salon dont les somptueuses décorations nous étonnèrent, mais que t'expliquera le récit de Michel. [Gide]

(100) An almost excessively frugal dinner was laid for us in a drawing room where the decorations were so sumptuous that we were astonished by them though they were afterwards explained by Michel's story.

Celle discusses this phenomenon insightfully (1997: 175-211), but there do not appear to be any implications for the null hypotheses.

As we found in the other direction in examples (43-8), there are some examples (18 in all) which use a very different construction in English:

(101) I have no objection to the minister replying briefly. [Canhans]

(102) Je ne m'opposerai pas à ce que le ministre réponde brièvement

(103) No one can feel more sensible than I do of the necessity of hereafter publishing in detail all the facts, with references, on which my conclusions have been grounded; and $\underline{I \text { hope in a future }}$ work to do this. [Scitec]

(104) Personne, plus que moi, ne comprend la nécessité de publier plus tard, en détail, tous les faits sur lesquels reposent mes conclusions; ce sera l'objet d'un autre ouvrage.

(105) Madeleine, jouez- moi un air, au phono, vous serez gentille. [Sartre]

(106) Madeleine, if you please, play something on the phonograph.

(107) La plupart des jeunes du Tiers-Monde ne fréquenteront jamais un collège d'enseignement technique à cause des frais de scolarité, encore moins une université. [Misc]

(108) For the bulk of the young people in the Third World, attendance at a fee-charging technical college, much less a university, is out of the question. 
Of the 192 instances of FFI that did not correspond to will, we have examined 67 that used the present tense, 53 where English introduced a modal expression, 9 examples in instructions, 9 where FFI looks forward in a narrative, and 18 "noisy" equivalents, a total of 156, leaving only $36(3 \%)$ unaccounted for. Of these 36, only 5 used be going to - a smaller number than the correspondences between will and aller + infinitive for reasons that we discussed above. We have not found anything that jeopardises the null hypotheses.

\section{Conclusion}

With the exception of the volitional use of will, the null hypotheses are confirmed: FFI and will can both be treated as markers of future tense; will also retains a volitional meaning element from its historical development, which is triggered in the right contexts. The two tenses are translation equivalents most of the time: where they are not, independent reasons can generally be found. There are some interesting differences in the way that FFI and will are used in texts, notably the use of FFI in narratives and the expression of characteristic properties by will: although a similar generic use of FFI can be found, e.g. example (15), this use of the future tense marker appears to be far more common in English.

We conclude that Lyons was wrong: futurity in English and French is often purely temporal, and there is no reason to complicate the semantics of FFI and will simply because the future is often uncertain.

\section{Appendix: Corpus texts}

\begin{tabular}{|l|l|}
\hline File & Extracts from: \\
\hline Bible & Genesis, Exodus, Psalms \\
\hline Canhans & Canadian Hansard (Reports of proceedings in the Canadian Parliament) \\
\hline Céline & Céline, Voyage au bout de la nuit \\
\hline Efict & English Fiction (B. Stoker, Dracula and H.G. Wells, The Invisible Man.) \\
\hline Ffict & French fiction (Verne, Germain, Saint-Exupéry, Camus) \\
\hline Gide & Gide, L'immoraliste. \\
\hline Instrs & Instructions for Xerox ScanWorx and various domestic appliances: \\
\hline Intorgs & International organisations (EU, ILO, UN) \\
\hline Malmau & Malraux and Maupassant short stories \\
\hline Misc & Canadian and French government texts \\
\hline News & Le Monde / Guardian Weekly \\
\hline Robbeg & Robbe-Grillet, La jalousie \\
\hline Sartre & Sartre, La Nausée. \\
\hline Scitec & $\begin{array}{l}\text { Scientific \& technical texts, including Darwin Origin of Species and texts } \\
\text { from the Institut Pasteur }\end{array}$ \\
\hline Whomal & World Health Organisation: Chemotherapy Of Malaria \\
\hline
\end{tabular}




\section{References}

Biber, D., S. Johansson, G. Leech, S. Conrad \& E. Finegan. (1999). Longman grammar of spoken and written English. London : Longman.

Caudal, P. \& C. Vetters. (2005). Un traitement conjoint du conditionnel, du futur et de l'imparfait : les temps comme des fonctions d'acte de langage. In Temporalité et attitude: structuration du discours et expression de la modalité, ed. A. Molendijk \& C. Vet, (Cahiers Chronos 12), 109-124. Amsterdam : Rodopi,

Celle, A. (1994). La traduction de WILL. Linguistique et Traduction, T. 3 (Paris, Ophrys), 87-139.

Celle, A. (1997). Étude contrastive du future français et de ses réalisations en anglais. Paris : Ophrys.

Celle, A. (2005). The French future tense and English will as markers of epistemic modality. Languages in Contrast, $5,181-218$.

Celle, A. (2006). Temps et modalité: l'anglais, le français et l'allemand en contraste. (Études contrastives vol. 7). Bern : Peter Lang.

Comrie, B. (1985). Tense. Cambridge : Cambridge University Press.

Fuchs, C. \& A.-M. Léonard. 1979. Vers une théorie des aspects. Paris : Mouton.

Haegeman, L. (1983). The semantics of will in Present-day British English: a unified account. Verhandelingen van de Koninklijke Academie voor Wetenschappen, Letteren en Schone Kunsten van België, Klasse de Letteren, Jaargang 45.

Huddleston, R. (1995). The case against a future tense in English. Studies in Language, 19, 399-446.

Huddleston, R. \& G. Pullum. (2002). The Cambridge grammar of the English language. Cambridge : Cambridge University Press.

Jespersen, O. (1933). Essentials of English grammar. London : George Allen \& Unwin.

Kissine, M. (2008). Why will is not a modal. Natural Language Semantics, 16, 129-155.

Larreya, P. (1996). Le temps grammatical : une question de mode? In Dynamique du temps, ed. A. Suberchicot, 13953. Clermont-Ferrand : CRLMC, Université Blaise Pascal.

Lévy, M. (2000). Grammaire du français: approche énonciative. Paris : Ophrys.

Lyons, J. (1977). Semantics. Cambridge : Cambridge University Press.

Mauranen, A. (1999). Will translationese ruin a contrastive study? Languages in Contrast, 2(2), 161-185.

Mauranen, A. (2008). Universal tendencies in translation. In Incorporating corpora: the linguist and the translator, ed. G. Anderman \& M. Rogers, 32-47. Clevedon : Multilingual Matters.

Reichenbach, H. (1947). Elements of Symbolic Logic. New York, NY : Macmillan.

Riegel, M., J.-C. Pellat \& R. Rioul. (1994). Grammaire méthodique du français. Paris : Presses Universitaires des France.

Rocci, A. (2000). L'interprétation épistémique du futur en italien et en français : une analyse procédurale. In Inférences directionnelles, représentations mentales et subjectivité, ed. J. Moeschler, Cahiers de linguistique française (Genève) 22, 241-274.

Salkie, R. (2008). The INTERSECT multilingual corpus. Information available on the web : http://artsresearch.brighton.ac.uk/research/academic/salkie/portfolio.

Vet, C. (1993). Conditions d'emploi et d'interprétation des temps futurs du français. Verbum, 16, 71-84.

Vet, C. (2003). Attitude, vérité et grammaticalisation: le cas du futur simple. In Aspects de la modalité, eds. M. Birkelund, G. Boysen \& P. S. Kjærsgaard, 229-239. Tübingen : Max Niemeyer.

Vetters, C. (1996). Temps, aspect et narration. Amsterdam : Rodopi.

Vogüé, S de. (1993). Des temps et des modes. Le Gré des Langues 6, 65-91. 
Welke, K. (2005). Tempus im Deutschen: Rekonstruktion eines semantischen Systems. (Linguistik - Impulse \& Tendenzen 13). Berlin : Walter de Gruyter.

${ }^{1}$ When using a parallel corpus as a source of data for contrastive linguistics, as in this paper, arguably the direction of translation for a particular example is not relevant as long as the translation is of good quality. See Mauranen (1999, 2008) for discussion.

2 For arguments that this two-morpheme analysis of the "future in the past" is correct, see Caudal \& Vetters (2005). In the light of this analysis, the traditional name "conditionnel" is inaccurate and should be discarded. 